\title{
The effects of dietary tryptophan levels on growth and metabolism of rainbow trout (Salmo gairdneri)
}

\author{
By M. J. WALTON, R. M. COLOSO*, C. B. COWEY, J. W. ADRON \\ AND D. KNOX \\ NERC Institute of Marine Biochemistry, St Fittick's Road, Aberdeen ABI 3RA
}

(Received 13 June 1983 - Accepted 10 October 1983)

1. Groups of rainbow trout (Salmo gairdneri) (mean weight $14 \mathrm{~g}$ ) were given diets containing $0 \cdot 8,1 \cdot 3,2,3,4$ or $6 \mathrm{~g}$ tryptophan $/ \mathrm{kg}$ diet for 12 weeks.

2. By analysis of the growth results, the dietary requirement of tryptophan was found to be $2.5 \mathrm{~g} / \mathrm{kg} \mathrm{diet}$ (equivalent to $50 \mathrm{mg} / \mathrm{kg}$ biomass per $\mathrm{d}$ ).

3. Carbon dioxide expired by trout following intraperitoneal injection of $\left[{ }^{14} \mathrm{COOH}\right]$ tryptophan contained little radioactivity when dietary tryptophan level was low but, above $2.0 \mathrm{~g} / \mathrm{kg}$ diet, it increased rapidly with increasing dietary tryptophan level. The break point in the dose-response curve did not, however, coincide with that from the growth results.

4. Changes in concentrations of free tryptophan in blood and liver and activity of hepatic tryptophan pyrrolase (EC 1.13.11.11) in response to changes in dietary tryptophan concentration did not provide reliable indicators for quantifying dietary requirement. Unlike the situation in mammals, blood tryptophan was not protein-bound to any appreciable extent. Tryptophan pyrrolase of trout has properties which suggest it has no apoenzyme form.

5. In fish given adequate levels of tryptophan injected intraperitoneally with a tracer dose of $\left[{ }^{14} \mathrm{COOH}\right]$ tryptophan, $60 \%$ of the dose was incorporated into body protein within $1 \mathrm{~d}$. The turnover of the label in this protein is very slow.

6. Those trout given diets deficient in tryptophan suffered from severe scoliosis and lordosis as well as having increased liver and kidney levels of calcium, magnesium, sodium and potassium.

As with most animals, tryptophan has been shown to be an essential dietary amino acid for those fish species so far studied (see Ketola, 1982). The quantitative requirement appears to vary with species, being $2 \mathrm{~g} / \mathrm{kg}$ diet for chinook salmon (Oncorhynchus tschawytscha) (Halver, 1965), $1.2 \mathrm{~g} / \mathrm{kg}$ for channel catfish (Ictalurus punctatus) (Wilson et al. 1978) and $4 \mathrm{~g} / \mathrm{kg}$ for Japanese eel (Anguilla japonica) (Nose, 1979). The requirement of rainbow trout (Salmo gairdneri) for tryptophan has not been quantified but its deficiency leads to several anatomical deformities such as scoliosis, lordosis and renal calcinosis (Kloppel \& Post, 1975). These symptoms were not seen in tryptophan-deficient catfish (Wilson et al. 1978).

In addition to being a constituent of protein, tryptophan has several other roles such as a precursor of serotonin and nicotinic acid and as a regulator of polysome function and carbohydrate metabolism (Wittman, 1976; Sidransky et al. 1981). Most of these roles have been little, if at all, studied in fish. The pathway leading to nicotinic acid formation has been studied by Poston \& Combs (1980) who concluded that it is of little significance to rainbow trout and hence nicotinic acid must be obtained from the diet. All diets in the present experiment contained adequate amounts of nicotinic acid $(0.75 \mathrm{~g} / \mathrm{kg}$ diet $)$, the dietary requirement being $0 \cdot 1-0.2 \mathrm{~g} / \mathrm{kg}$ (Halver, 1982). In most animals tryptophan oxidation is usually incomplete and the enzyme thought to initiate the principal catabolic pathway is tryptophan pyrrolase $(E C 1.13 .11 .11)$ which occurs mainly in the liver (Bender, 1978).

The purpose of the present paper was to quantify the dietary requirement of rainbow trout for tryptophan and to examine the effects of variation in tryptophan intake on levels

* Present address: Aquaculture Department, S.E. Asian Development Centre, Tigbauan, Iloilo, Philippines. 
of the free amino-acid in blood and liver, activities of hepatic tryptophan pyrrolase and oxidation of $\mathrm{L}-\left[{ }^{14} \mathrm{COOH}\right]$ tryptophan. Some further investigations on liver and kidney levels of several minerals were also performed.

\section{EXPER IMENTAL}

\section{Fish and diets}

Rainbow trout (from Highlands and Islands Development Board, Inverness) of approximately $14 \mathrm{~g}$ mean weight were randomly distributed (forty fish per tank) amongst six circular glass-fibre tanks of diameter $1 \mathrm{~m}$, depth $0.6 \mathrm{~m}$ and each containing $500 \mathrm{l}$ water (a mixture of 2 vol. fresh water: 1 vol. sea water). The water from the tanks was mainly (95\%) recirculated with approximately $5 \%$ of new water mixture being bled into the system continuously and a similar amount being removed; tank water temperature was $15 \pm 1^{\circ}$. The fish, which had previously been fed on a commercial hatchery diet, were weaned on to an experimental diet (diet 6, Table 1) and when the experiment started they were fed on a restricted ration amounting to $20 \mathrm{~g}$ dry weight diet $/ \mathrm{kg}$ live weight fish per $\mathrm{d}$ for $6 \mathrm{~d}$ each week. This quantity of diet was readily eaten without wastage at 3-4 feeds/d. The compositions of the six experimental diets are shown in Table 1. In over-all amino acid composition, the diets simulated cod white-muscle. (Crude protein content of the diets was calculated to be $55 \%$ dry weight.) The diets were prepared as moist pellets which were then freeze-dried and stored at $-20^{\circ}$ until required. The fish were weighed individually every 4 weeks for 12 weeks and the daily ration adjusted after each weighing.

Those fish used for tryptophan turnover studies were given a casein control diet prepared as described previously (Walton et al. 1982).

\section{Analysis for tryptophan}

Dietary protein constituents were subjected to alkaline hydrolysis and assayed colorimetrically for tryptophan by the method of Basha \& Roberts (1977). The level of tryptophan in the white fish-meal used for the diets was found to be $6.53 \mathrm{~g} / \mathrm{kg}$; tryptophan was barely, if at all, detectable in gelatin. For the measurement of tryptophan in liver and blood samples, the fluorimetric method of Denkla \& Dewey (1967), as modified by Bloxam \& Warren (1974), was used. Blood was taken from the caudal vein using heparinized syringes and assayed within a few hours, whereas liver samples were freeze-clamped in liquid nitrogen and assayed the following day. Blood and liver samples were taken either 6 or $20 \mathrm{~h}$ after feeding. Plasma was obtained by centrifugation of blood samples and, in some samples, free tryptophan was separated from bound tryptophan by ultrafiltration (Fuller \& Roush, 1973).

\section{Measurement of tryptophan pyrrolase}

The enzyme was assayed by the method of Badawy \& Evans (1975) except that the volume of the incubation mixture was scaled down fivefold and a more concentrated homogenate was used ( $1 \mathrm{~g}$ wet weight liver plus $3 \mathrm{ml}$ homogenizing medium). Incubations were performed at $20^{\circ}$, at $\mathrm{pH} 7$ for $0,30,60$ and $90 \mathrm{~min}$.

\section{Oxidation of $\left[{ }^{14} \mathrm{C}\right]$ tryptophan}

L- $\left[{ }^{14} \mathrm{COOH}\right]$ tryptophan $(50 \mu \mathrm{Ci} / \mu \mathrm{mol})$ was obtained from Amersham International (Amersham). A solution of the isotope in $0.154 \mathrm{M}$-sodium chloride was prepared such that $100 \mu \mathrm{l}$ contained $1 \mu \mathrm{Ci}$. One $\mu \mathrm{Ci}$ was injected intraperitoneally into each fish at 13.00 hours and the carbon dioxide respired between then and 09.00 hours the following day collected by the procedure described previously (Walton et al. 1982) except that the fish were kept in 31 of water and were not starved overnight preceding the experiment. 
Table 1. Composition ( $\mathrm{g} / \mathrm{kg} d r y$ diet) of experimental diets

\begin{tabular}{|c|c|c|c|c|c|c|}
\hline \multirow[b]{2}{*}{ Component } & \multicolumn{6}{|c|}{ Diet } \\
\hline & 1 & 2 & 3 & 4 & 5 & 6 \\
\hline $\begin{array}{l}\text { Basal mix* } \\
\text { L-Tryptophan } \\
\text { Potato starch }\end{array}$ & $\begin{array}{c}838 \cdot 9 \\
0 \\
161 \cdot 1\end{array}$ & $\begin{array}{r}838.9 \\
0.5 \\
160.6\end{array}$ & $\begin{array}{r}838.9 \\
1.2 \\
159.9\end{array}$ & $\begin{array}{r}838.9 \\
2.2 \\
158.9\end{array}$ & $\begin{array}{r}838.9 \\
3.2 \\
157.9\end{array}$ & $\begin{array}{r}838.9 \\
5.2 \\
155.9\end{array}$ \\
\hline Total tryptophan & $0 \cdot 8$ & $1 \cdot 3$ & $2 \cdot 0$ & $3 \cdot 0$ & $4 \cdot 0$ & 6.0 \\
\hline
\end{tabular}

* Basal mix supplied (g/kg dry weight complete diet): white fishmeal 120 ; gelatin 250 , capelin oil 150 , mineral mix 40 , vitamin mix 28 , DL- $\alpha$-tocopheryl acetate $0 \cdot 1$, butylated hydroxyanisole $0 \cdot 5$, ascorbyl palmitate $0 \cdot 4$, amino acid mix 250. For composition of the mineral and vitamin mixes see Cowey et al. (1981). The amino acid mix consisted of a mixture of $\mathrm{L}$-amino acids as follows $(\mathrm{g} / \mathrm{kg}$ mix): alanine $11 \cdot 6$, arginine 26.4 , aspartic acid $26 \cdot 9$, cyst(e)ine $23 \cdot 2$, glutamic acid $154 \cdot 8$, histidine $45 \cdot 2$, isoleucine $61 \cdot 2$, lysine $124 \cdot 4$, leucine $113 \cdot 6$, methionine $17 \cdot 6$, phenylalanine $48 \cdot 8$, serine $70 \cdot 4$, tyrosine $54 \cdot 0$, threonine $61 \cdot 2$, valine $82 \cdot 0$.

\section{Turnover of $\left[{ }^{14} C\right]$ tryptophan}

One $\mu \mathrm{Ci} \mathrm{L}-\left[{ }^{14} \mathrm{COOH}\right]$ tryptophan ( $100 \mu$ l of the above solution) was injected intraperitoneally into each of twenty fish (mean weight $45 \mathrm{~g}$ ) that were being grown on a diet containing $45 \%$ crude protein (casein) (Walton et al. 1982). The fish were given this diet throughout the course of the experiment. At 1, 3, 7, 15, 21 and $28 \mathrm{~d}$, three fish were taken and killed. The livers were treated as described previously (Walton et al. 1982) to yield soluble, lipid and protein fractions. The remainder of each fish (i.e. everything but the liver) was homogenized in 61 ethanol: $\mathrm{H}_{2} \mathrm{O}(4: 1, \mathrm{v} / \mathrm{v})$ per $\mathrm{kg}$ fish using a Townson-Mercer top-drive macerator. The homogenate was filtered through a sintered glass funnel (porosity 3) and washed through successively with $100 \mathrm{ml} 0.5 \mathrm{M}$-perchloric acid and $100 \mathrm{ml}$ acetone. The pellet was then continuously extracted with ether for $6 \mathrm{~h}$, dried and weighed. Half of it was dissolved in $50 \mathrm{ml} 2 \mathrm{M}$-potassium hydroxide and aliquots assayed for radioactivity.

\section{Mineral analysis}

Calcium, sodium, potassium, phosphorus, magnesium and zinc were analysed in kidney and liver samples after dry ashing as described by Cowey et al. (1977).

\section{Statistical analysis}

In the prevailing circumstances it was not possible to allocate more than a single tank to each experimental treatment and the measurements made on each fish were treated as separate biological observations. While there may be a danger of confounding treatments with tanks, no tank effects have previously been observed in the tanks that were used (Knox et al. 1983). In addition, potential tank effects were minimized by changing the tank for each treatment at the periodic weighing. Finally, trends typical of dose response relationships were clearly evident between certain characteristics (e.g. weight gain, oxidation of radioactive tryptophan) and dietary tryptophan concentration. All data were subjected to analysis of variance and, if appropriate, Duncan's multiple range test (Steel \& Torrie, 1980) was applied to determine if the differences between means were statistically significant.

\section{RESULTS}

Weight gains, food conversion ratios, specific growth rates and mortalities of trout given the six experimental diets are shown in Table 2. The fish given diets 1 and 2 grew considerably less well and suffered more mortalities than the fish given the other four diets. 
Table 2. Growth of fish given diets containing different levels of tryptophan for 12 weeks*

\begin{tabular}{lccccccc}
\hline & \multicolumn{7}{c}{ Diet } \\
\cline { 2 - 7 } & 1 & 2 & 3 & 4 & 5 & 6 & SEM \\
\hline $\begin{array}{c}\text { Dietary } \\
\text { tryptophan }(\mathrm{g} / \mathrm{kg})\end{array}$ & 0.8 & 1.3 & 2.0 & 3.0 & 4.0 & 6.0 & - \\
$\begin{array}{c}\text { Mean initial } \\
\text { weight (g) }\end{array}$ & 13.55 & 13.84 & 13.69 & 14.02 & 13.86 & 13.60 & - \\
$\begin{array}{c}\text { Mean final } \\
\text { weight (g) }\end{array}$ & $19.14^{a}$ & $28.86^{b}$ & $44.07^{c}$ & $53.02^{c}$ & $52.95^{c}$ & $49.43^{c}$ & 1.22 \\
$\begin{array}{c}\text { Mean weight } \\
\text { gain (\%) }\end{array}$ & 41.3 & 108.5 & 221.9 & 278.2 & 282.0 & 263.4 & - \\
$\begin{array}{c}\text { Specific growth } \\
\text { rate } \dagger\end{array}$ & 0.41 & 0.87 & 1.39 & 1.58 & 1.60 & 1.54 & - \\
$\begin{array}{c}\text { Food conversion } \\
\text { ratio }\end{array}$ & 4.01 & 1.74 & 0.93 & 0.80 & 0.80 & 0.82 & - \\
Mortalities & 4 & 5 & 2 & 0 & 0 & 0 & - \\
\hline \hline
\end{tabular}

$a, b, c$ Mean values within a row not sharing a common superscript were significantly different: $P<0.05$.

* For details of diets, see Table 1.

+100 (In (final weight) $-\ln ($ initial weight)) $/ 84 \mathrm{~d}$.

$\$$ Dry weight food $(\mathrm{g})$ : wet weight gain $(\mathrm{g})$.

In fact, there was a sixfold difference in mean weight gain between those fish on diet 1 and those on diets 4-6. No signs of anorexia were observed in any of the fish but about 70 and $40 \%$ of fish given, respectively, diets 1 and 2 suffered from scoliosis. Only two of the fish on diet 3 and none of those on the remaining diets showed this symptom. Nearly all the fish given diets 1,2 and 3 had eye cataracts compared with occurrences of 20,0 and $5 \%$ in fish given diets 4,5 , and 6 respectively. When the weight gains were plotted against levels of tryptophan in the diet (Fig. 1) a break-point occurs (between diets 3 and 4) at approximately $2.5 \mathrm{~g} / \mathrm{kg}$ diet $(50 \mathrm{mg} / \mathrm{kg}$ biomass per d) and this is taken as the dietary requirement level. This requirement, based on weight gain, corresponds well with the dietary level required to prevent mortalities and deficiency pathologies; it also corresponds with maximal food conversion ratio.

The effects of the different dietary treatments on several liver and blood constituents are shown in Table 3. Values for hepatosomatic index were high; values were usually approximately $1.5 \%$. These values may reflect an accumulation of glycogen resulting from the presence in the diet of high levels of free amino acids together with appreciable amounts of starch. Among treatments, hepatosomatic index was not greatly influenced by diet although it was significantly lower in those fish on diet 1 compared with those fish on diets 3-6. Levels of tryptophan in blood and liver, however, were markedly affected by the dietary levels of the amino acid, in that increases in dietary levels were reflected by higher tissue levels. When these two factors were plotted, no break-point or sudden increase in slope was seen at the requirement level defined from the growth studies.

In fish given diet 6, the levels of free and bound tryptophan in plasma were measured. Very low levels of bound tryptophan were found, the values (mean with SE) being 38.03 $(2.82) \mathrm{nmol}$ total tryptophan $/ \mathrm{ml}$ and $37.37(2.27) \mathrm{nmol}$ free tryptophan/ml, giving by difference a figure of $2 \%$ bound tryptophan.

In preliminary studies on tryptophan pyrrolase in rainbow trout no activity could be detected in kidney, gills, red muscle or white muscle. The liver enzyme, located in the cytosol, had a broad $\mathrm{pH}$ optimum of approximately 7 , and was not stimulated by haematin. There 


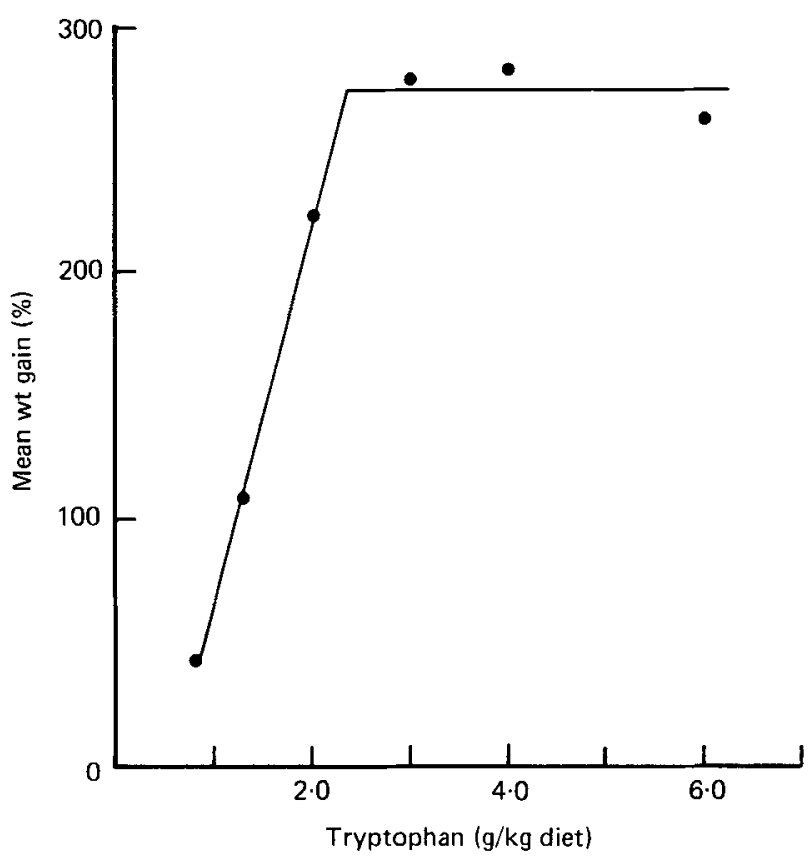

Fig. 1. Mean weight gain of rainbow trout (forty fish per treatment) given six different levels of dietary tryptophan for 12 weeks.

was considerable variation in the activities of the enzyme in each of the groups tested and hence no consistent effect of diet on levels of the liver enzyme was observed.

Table 4 shows the effect of diet on the oxidation of an injected dose of $\left[{ }^{14} \mathrm{COOH}\right]$ tryptophan over a $20 \mathrm{~h}$ period. In those fish given diets $1-3$, the level of oxidation was relatively low but was successively markedly increased in fish given diets 4,5 and 6 . When plotted graphically the break-point occurs at about $2 \mathrm{~g}$ tryptophan $/ \mathrm{kg}$ diet, a value less than that determined by the growth response curve.

From Table 5 it can be seen that an injected dose of tryptophan was rapidly incorporated into body protein $(60 \%$ dose within $1 \mathrm{~d})$ but once incorporated, the loss of label was slow, $51 \%$ dose remaining after $28 \mathrm{~d}$. Semi-log plots of the data were non-linear as is often found with complex mixtures of proteins (Garlick et al. 1976). Since the loss of label was so slow it was not possible to analyse the decay curves with any degree of accuracy, to give average turnover rates.

Table 6 shows the concentrations of several minerals in the kidneys taken from fish fed on the six experimental diets. There were significantly greater concentrations of $\mathrm{Ca}, \mathrm{Na}$ and $K$ in the kidneys of the most tryptophan-deficient trout (treatments 1 or 1 and 2) than in those of trout given diets 3-6. No significant trends wero evident in the concentrations of other minerals examined.

The concentrations of $\mathrm{Ca}, \mathrm{Mg}, \mathrm{Na}$ and $\mathrm{K}$ in the livers of tryptophan-deficient trout (Table 7) were also significantly greater than those of normal trout. Enhancement of hepatic $\mathrm{Ca}$ and $\mathrm{Na}$ concentrations in the deficient fish was less marked than was the case with renal levels of these metals. X-ray photographs were taken of a scoliotic and a normal fish; a pronounced lateral curvature was seen in the spine of the scoliotic fish although no compacting of the vertebrae was apparent. 
Table 3. Hepatosomatic index (HSI), levels of tryptophan in liver and blood, and activities of liver tryptophan pyrrolase (EC 1.13.11.11) in rainbow trout given diets* containing different levels of tryptophan

\begin{tabular}{|c|c|c|c|c|c|c|c|c|}
\hline & & \multicolumn{6}{|c|}{ Diet } & \multirow[b]{2}{*}{ SEM } \\
\hline & & 1 & 2 & 3 & 4 & 5 & 6 & \\
\hline $\begin{array}{l}\text { Dietary tryptophan } \\
(\mathrm{g} / \mathrm{kg})\end{array}$ & - & 0.8 & $1 \cdot 3$ & $2 \cdot 0$ & $3 \cdot 0$ & 4.0 & 6.0 & \\
\hline HSI & $(12)_{\ddagger}^{\ddagger}$ & $1 \cdot 80^{\alpha}$ & $2 \cdot 39^{a b}$ & $2 \cdot 83^{b}$ & $2 \cdot 83^{b}$ & $2 \cdot 80^{b}$ & $2 \cdot 73^{b}$ & 0.15 \\
\hline $\begin{array}{l}\text { Blood tryptophan } \\
(6 \mathrm{~h})(\mu \mathrm{M})\end{array}$ & $(3)$ & $2 \cdot 92^{a}$ & $4 \cdot 13^{a}$ & $16 \cdot 49^{b}$ & $22 \cdot 13^{b c}$ & $27 \cdot 58^{c}$ & $38 \cdot 50^{a}$ & $2 \cdot 26$ \\
\hline $\begin{array}{l}\text { Blood tryptophan } \\
(20 \mathrm{~h})(\mu \mathrm{M})\end{array}$ & (4) & $1.63^{a}$ & $5 \cdot 94^{a}$ & $12 \cdot 38^{b}$ & $18 \cdot 33^{b c}$ & $23 \cdot 63^{c}$ & $20 \cdot 67^{c}$ & 2.09 \\
\hline $\begin{array}{l}\text { Liver tryptophan } \\
(20 \mathrm{~h})(\mu \mathrm{mol} / \mathrm{kg})\end{array}$ & (5) & $6 \cdot 51^{a}$ & $9 \cdot 47^{a}$ & $15 \cdot 46^{b c}$ & $17 \cdot 11^{b d}$ & $21 \cdot 15^{d}$ & $20 \cdot 72^{c d}$ & $1 \cdot 62$ \\
\hline $\begin{array}{l}\text { Tryptophan } \\
\text { pyrrolase }(\mu \mathrm{mol} / \mathrm{h} \\
\text { per g protein })\end{array}$ & $(5)$ & $5 \cdot 1$ & $13 \cdot 3$ & $8 \cdot 8$ & $15 \cdot 9$ & $14 \cdot 2$ & $12 \cdot 8$ & 3.47 \\
\hline
\end{tabular}

$a, b, c, d$ Mean values within a row not sharing a common superscript were significantly different: $P<0 \cdot 05$.

* For details of diets, see Table 1.

$\dagger$ HSI $=(100 \times$ liver weight $(\mathrm{g})) /$ body-weight $(\mathrm{g})$.

\$ Values in brackets are the number of individuals for each mean value in the row.

Table 4. Oxidation of $L-\left[{ }^{14} \mathrm{COOH}\right]$ tryptophan for $20 \mathrm{~h}$ at $15^{\circ}$ by rainbow trout given diets* containing different levels of tryptophan

\begin{tabular}{|c|c|c|c|c|c|c|c|}
\hline & \multicolumn{6}{|c|}{ Diet } & \multirow[b]{2}{*}{ SEM } \\
\hline & 1 & 2 & 3 & 4 & 5 & 6 & \\
\hline Dietary tryptophan $(\mathrm{g} / \mathrm{kg})$ & 0.8 & $1 \cdot 3$ & $2 \cdot 0$ & $3 \cdot 0$ & $4 \cdot 0$ & $6 \cdot 0$ & \\
\hline Dose oxidized $(\%) \dagger$ & $3 \cdot 13^{a}$ & $3 \cdot 31^{a}$ & $4 \cdot 5^{a}$ & $13 \cdot 40^{b}$ & $22 \cdot 44^{c}$ & $31 \cdot 98^{d}$ & 1.48 \\
\hline
\end{tabular}

$a, b, c, d$ Mean values not sharing a common superscript were significantly different: $P<0 \cdot 05$.

* For details of diets, see Table 1.

$\dagger$ Each value is the mean of three individuals.

Table 5. Radioactivity in liver and body proteins during $28 \mathrm{~d}$ post-injection of $1 \mu \mathrm{Ci}$ $L\left[{ }^{14} \mathrm{COOH}\right]$ tryptophan into trout*

\begin{tabular}{lcccccc}
\hline \hline & \multicolumn{5}{c}{ Days post-injection } \\
\cline { 2 - 7 } & 1 & 2 & 7 & 14 & 21 & 28 \\
\hline Body protein (\% dose) & $59 \cdot 02$ & $67 \cdot 02$ & $59 \cdot 02$ & $54 \cdot 32$ & $51 \cdot 67$ & $50 \cdot 96$ \\
Liver protein (\% dose) & $2 \cdot 52$ & $1 \cdot 80$ & $2 \cdot 12$ & $1 \cdot 37$ & $1 \cdot 57$ & $1 \cdot 37$ \\
$\begin{array}{l}\text { Liver protein } \\
\text { (disintegrations/min }\end{array}$ & 1038 & 685 & 596 & 540 & 407 & 434 \\
per mg protein) & & & & & \\
\hline \hline
\end{tabular}

* Fish were fed on a casein control diet (Walton et al. 1982). Each value is the mean of three individuals. 
Table 6. Mean concentrations of calcium, magnesium, zinc, sodium, potassium and phosphorus (mmol/kg dry weight) in kidneys of rainbow trout given diets* containing different levels of tryptophan

(Mean values for six fish per treatment)

\begin{tabular}{lccccccc}
\hline \hline & \multicolumn{7}{c}{ Diet } \\
\cline { 2 - 7 } Mineral & 1 & 2 & 3 & 4 & 5 & 6 & SEM \\
\hline & & & & & & \\
$\mathrm{Ca}$ & $63 \cdot 66^{a}$ & $25 \cdot 25^{b}$ & $14 \cdot 24^{b}$ & $14 \cdot 95^{b}$ & $17 \cdot 49^{b}$ & $16 \cdot 13^{b}$ & $10 \cdot 06$ \\
$\mathrm{Mg}$ & $37 \cdot 34^{a}$ & $33 \cdot 33^{b c}$ & $32 \cdot 64^{b c}$ & $34 \cdot 64^{a c}$ & $34 \cdot 19^{a c}$ & $33 \cdot 55^{b c}$ & $0 \cdot 94$ \\
$\mathrm{Zn}$ & $1 \cdot 86^{a}$ & $1 \cdot 59^{b c}$ & $1 \cdot 56^{b c}$ & $1 \cdot 69^{a c}$ & $1 \cdot 74^{a c}$ & $1 \cdot 74^{a c}$ & $0 \cdot 06$ \\
$\mathrm{Na}$ & $947^{a}$ & $565^{b}$ & $358^{c}$ & $352^{c}$ & $385^{c}$ & $362^{c}$ & $15 \cdot 1$ \\
$\mathrm{~K}$ & $450^{a}$ & $358^{b}$ & $312^{c}$ & $320^{c}$ & $312^{c}$ & $312^{c}$ & $12 \cdot 7$ \\
$\mathrm{P}$ & $450^{a}$ & $395^{a}$ & $417^{a}$ & $428^{a}$ & $410^{a}$ & $408^{a}$ & $13 \cdot 2$ \\
\hline \hline
\end{tabular}

$a, b, c$ Mean values within the same row not sharing a common superscript were significantly different: $P<0.05$.

* For details of diets, see Table 1.

Table 7. Mean concentrations (mmol/kg dry weight) of calcium, magnesium, sodium and potassium in livers of rainbow trout given diets* containing different levels of tryptophan

(Mean values for six fish per treatment)

\begin{tabular}{|c|c|c|c|c|c|c|c|}
\hline \multirow[b]{2}{*}{ Mineral } & \multicolumn{6}{|c|}{ Diet } & \multirow[b]{2}{*}{ SEM } \\
\hline & 1 & 2 & 3 & 4 & 5 & 6 & \\
\hline $\mathrm{Ca}$ & $7 \cdot 41^{a}$ & $5 \cdot 56^{a}$ & $4 \cdot 78^{b}$ & $4 \cdot 00^{b}$ & $3.89^{b}$ & $4 \cdot 42^{b}$ & 0.51 \\
\hline $\mathrm{Mg}$ & $33 \cdot 23^{a}$ & $28 \cdot 05^{b}$ & $25 \cdot 86^{b c}$ & $20 \cdot 64^{c}$ & $19 \cdot 57^{c}$ & $23 \cdot 12^{c}$ & 1.26 \\
\hline $\mathrm{Na}$ & $405^{a}$ & $308^{b}$ & $242^{b c}$ & $213^{c}$ & $200^{c}$ & $227^{b c}$ & 24 \\
\hline $\mathbf{K}$ & $422^{a}$ & $373^{a b}$ & $347^{b c}$ & $292^{c}$ & $265^{c}$ & $295^{c}$ & 17 \\
\hline
\end{tabular}

$a, b, c$ Mean values within the same row not sharing a common superscript were significantly different: $P<0 \cdot 05$.

* For details of diets, see Table 1.

\section{DISCUSSION}

The dietary requirement of rainbow trout for tryptophan, derived from the growth results in Table 2 , is $2.5 \mathrm{~g} / \mathrm{kg}$ diet. This value is approximately double that obtained by Wilson et al. (1978) for channel catfish and much lower than that obtained by Nose (1979) for Japanese eel. In terms of intake, requirements of rainbow trout and channel catfish are almost 50 and $38 \mathrm{mg} / \mathrm{kg}$ biomass per $\mathrm{d}$ respectively (insufficient information is provided for obtaining the equivalent value for Japanese eel). Consequently it is premature to conclude that requirements of different species for tryptophan are as disparate as they may seem at first.

It has been shown in a number of animal species (see Lewis et al. 1977) that when they are given diets containing increasing levels of a 'deficient' amino acid the blood level remains relatively low until the dietary requirement is exceeded, when the level rises sharply. However, it is often found that this 'break-point' tends to be at a lower dietary level than that found by growth response curves and often a well defined 'break-point' is not always observed. In studies on the catfish, several amino acids (lysine, methionine, cystine, threonine) produced well-defined 'break-points' by this procedure, whereas others (leucine, isoleucine, valine, tyrosine, phenylalanine) did not (Robinson et al. 1981). Absorption of amino acids follows a much longer time course in trout than in warm-blooded mammals. 
A recent study by Yamada et al. (1981) showed that maximum blood amino acid concentrations occurred $24-36 \mathrm{~h}$ after giving a casein meal and 12-24 h after giving a meal of free amino acids. Work on rats (McLaughlan \& Illman, 1967) has shown that blood samples taken $6 \mathrm{~h}$ after a meal give the best relationship of blood amino acid levels to adequacy of dietary intake. Few such studies have been carried out with fish to determine the optimum sampling time; Kaushik (1979) found that sampling $16 \mathrm{~h}$ after feeding was best for determining arginine requirements. In this study, blood samples were collected at 6 and $20 \mathrm{~h}$ and liver samples at $20 \mathrm{~h}$ after feeding. In none of these cases was a very sharp inflection observed from the plotted results.

In warm-blooded animals, a considerable proportion (75\%) of tryptophan in plasma is bound to protein whereas in trout very little, if any, tryptophan was found in the bound state. The fish is a cold-blooded species and a similar lack of binding has been found in frog blood by Fuller \& Roush (1973) and Badawy \& Evans (1976). The physiological significance of these species differences is unknown.

In this study no consistent relationship between dietary tryptophan level and activity of hepatic tryptophan pyrrolase was detected. In rat liver, the enzyme is regulated by the circulating concentration of its substrate and by several hormones and can be induced by hydrocortisone or tryptophan (Feigelson \& Greengard, 1962). However, Brown \& Dodgen (1968) found that administration of ACTH or three glucocorticoids or repeated doses of tryptophan into channel catfish failed to induce the liver enzyme. Studies by Badaway \& Evans $(1975,1976)$ have shown that, in some animal species such as rat, pig and chicken, the enzyme exists as the holoenzyme and apoenzyme wheres in other species such as cat, sheep and rabbit the apoenzyme is absent. When the apoenzyme is absent there is no hormonal induction, no stimulation by haematin, and the animals are more sensitive to tryptophan toxicity. The results in the present study suggest that the trout enzyme is similar to the catfish enzyme (no stimulation by haematin or apparent response to increased tryptophan levels). Even in the rat, liver tryptophan pyrrolase activity was not consistently related to dietary content (Lewis et al. 1977). Thus it is likely in trout that control of tryptophan catabolism is more likely to be related to tissue substrate concentration than levels of tryptophan pyrrolase. Alternatively, tryptophan may be catabolized by other routes such as the indoleamine pathway found in cattle (Yang \& Carlson, 1972).

${ }^{14} \mathrm{CO}_{2}$ production from injected $\left[{ }^{14} \mathrm{C}\right]$ tryptophan was found to increase sharply when dietary tryptophan levels were above $2 \mathrm{~g} / \mathrm{kg}$. At sub-optimal dietary intakes the tryptophan would be required mainly for protein synthesis, but once this demand had been met any additional tryptophan would be oxidized. The break-point from the oxidation results (Table 4) thus gives a dietary requirement close to, but slightly lower than, the value obtained from the growth results. This may result from a small but constant maintenance requirement.

Kloppel \& Post (1975) observed Ca deposition in the kidneys of tryptophan-deficient trout; urinary calculi occurred in many of the kidney tubules. The authors were not able to explain the abnormal deposition of $\mathrm{Ca}$ on the basis of known tryptophan metabolism although they speculated on an effect via Ca-regulating hormones or enzyme systems essential for $\mathrm{Ca}$ metabolism. The results reported in this paper show that the disturbance in mineral metabolism is not unique to Ca nor to the kidney.

The trout used by Kloppel \& Post (1975) were reared in freshwater with a Ca hardness of 200-234 ppm, in which they would produce large amounts of dilute urine. Those in the present experiment were reared in approximately isotonic sea water when much smaller amounts of more concentrated urine would be produced. In view of the similarity in kidney $\mathrm{Ca}$ disturbance in the two experiments it seems unlikely that the pathology can be linked to water supply - another possibility raised by Kloppel \& Post (1975). 
The disturbance to mineral metabolism caused by tryptophan deficiency differs from that arising from other causes such as $\mathrm{Mg}$ deficiency (Knox et al. 1981) in that all those ions affected, increase in concentration. Most notably both the main intracellular monovalent cation $(\mathrm{K})$ and the main extracellular monovalent cation $(\mathrm{Na})$ increase in concentration; there is no sign that balance between intracellular and extracellular compartments is affected. It is also of interest that liver is relatively unaffected by disturbances in mineral metabolism arising from $\mathrm{Mg}$ deficiency (Knox et al. 1981). It appears, therefore, that the observed abnormalities in tissue mineral levels stem from a derangement of tryptophan metabolism.

It is necessary to know more about tryptophan metabolism in the trout before the effects on tissue mineral levels and the appearance of scoliosis in fish given tryptophan-deficient diets can be explained. The formation of eye cataracts in tryptophan-deficient fish is probably due to alterations in the protein pattern of lens tissue, similar to that observed in salmon given a methionine-deficient diet (Barash et al. 1982).

\section{REFERENCES}

Badaway, A. A. B. \& Evans, M. (1975). Biochemical Journal 150, 511-520.

Badaway, A. A. B. \& Evans, M. (1976). Biochemical Journal 158, 79-88.

Barash, H., Poston, H. A. \& Rumsey, G. L. (1982). Cornell Veterinarian 72, 361-371.

Basha, S. M. M. \& Roberts, R. M. (1977). Analytical Biochemistry 77, 378-386.

Bender, D. A. (1978). Amino Acid Metabolism. Chichester: John Wiley \& Sons.

Bloxam, D. L. \& Warren, W. H. (1974). Analytical Biochemistry 60, 621-625.

Brown, J. N. \& Dodgen, C. L. (1968). Biochimica Biophysica Acta 165, 463-469.

Cowey, C. B., Adron, J. W., Walton, M. J., Murray, J., Youngson, A. \& Knox, D. (1981). Journal of Nutrition 111, 1556-1567.

Cowey, C. B., Knox, D., Adron, J. W., George, S. \& Pirie, B. (1977). British Journal of Nutrition 38, $127-135$.

Denkla, W. D. \& Dewey, H. K. (1967). Journal of Laboratory Clinical Medicine 69, 160-169.

Feigelson, P. \& Greengard, O. (1962). Journal of Biological Chemistry 237, 3714-3717.

Fuller, R. W. \& Roush, B. W. (1973). Comparative Biochemistry and Physiology B, 46, 273-276.

Garlick, P. J., Waterlow, J. C. \& Swick, R. W. (1976). Biochemical Journal 156, 657-663.

Halver, J. E. (1965). Federation Proceedings 24, 229.

Halver, J. E. (1982). Comparative Biochemistry and Physiology B, 73, 43-50.

Kaushik, S. (1979). In Finfish Nutrition and Fishfeed Technology, pp. 197-208 [J. E. Halver and K. Tiews, editors]. Berlin: Heenemann.

Ketola, H. G. (1982). Comparative Biochemistry and Physiology B, 73, 17-24.

Kloppel, T. M. \& Post, G. (1975). Journal of Nutrition 105, 861-866.

Knox, D., Cowey, C. B. \& Adron, J. W. (1981). British Journal of Nutrition 45, 137-148.

Knox, D., Cowey, C. B. \& Adron, J. W. (1983). British Journal of Nutrition 50, 121-127.

Lewis, A. J., Peo, E. R., Cunningham, P. J. \& Moser, B. D. (1977). Journal of Nutrition 107, $1361-1368$.

McLaughlan, J. M. \& Illman, W. E. (1967). Journal of Nutrition 93, 21-24.

Nose, T. (1979). In Finfish Nutrition and Fishfeed Technology, pp. 145-156 [J. E. Halver and K. Tiews, editors]. Berlin: Heenemann.

Poston, H. A. \& Combs, G. F. (1980). Proceedings of The Society of Experimental Biology and Medicine 163, $452-454$.

Robinson, E. H., Wilson, R. P. \& Poe, W. E. (1981). Journal of Nutrition 111, 46-52.

Sidransky, H., Verney, E. \& Murty, C. N. (1981). Journal of Nutrition 111, 1942-1948.

Steel, R. G. D. \& Torrie, J. H. (1980). Principles and Procedures of Statistics. New York: McGraw-Hill.

Walton, M. J., Cowey, C. B. \& Adron, J. W. (1982). Journal of Nutrition 112, 1525-1535.

Wilson, R. P., Allen, O. W., Robinson, E. H. \& Poe, W. E. (1978). Journal of Nutrition 108, $1595-1599$.

Wittman, J. S. (1976). Journal of Nutrition 106, 631-635.

Yamada, S., Simpson, K. L., Tonaka, Y. \& Katayama, T. (1981). Bulletin of the Japanese Society of Scientific Fisheries 47, 1035-1040.

Yang, J. N. Y. \& Carlson, J. R. (1972). Journal of Nutrition 102, 1655-1665.

Young, V. R. \& Munro, H. N. (1973). Journal of Nutrition 103, 1756-1763. 